放射線と白血病儿関する実験的研究

\author{
第 2 編 \\ X 線照射の造血臓器に及ぼす影響に関する \\ 各種系統マウスの比較研究
}

岡山大学医学部平朴内科教室 (主任 : 平水橴教授)

池居孝治

〔昭和 39 年 12 月 19 日受稿】

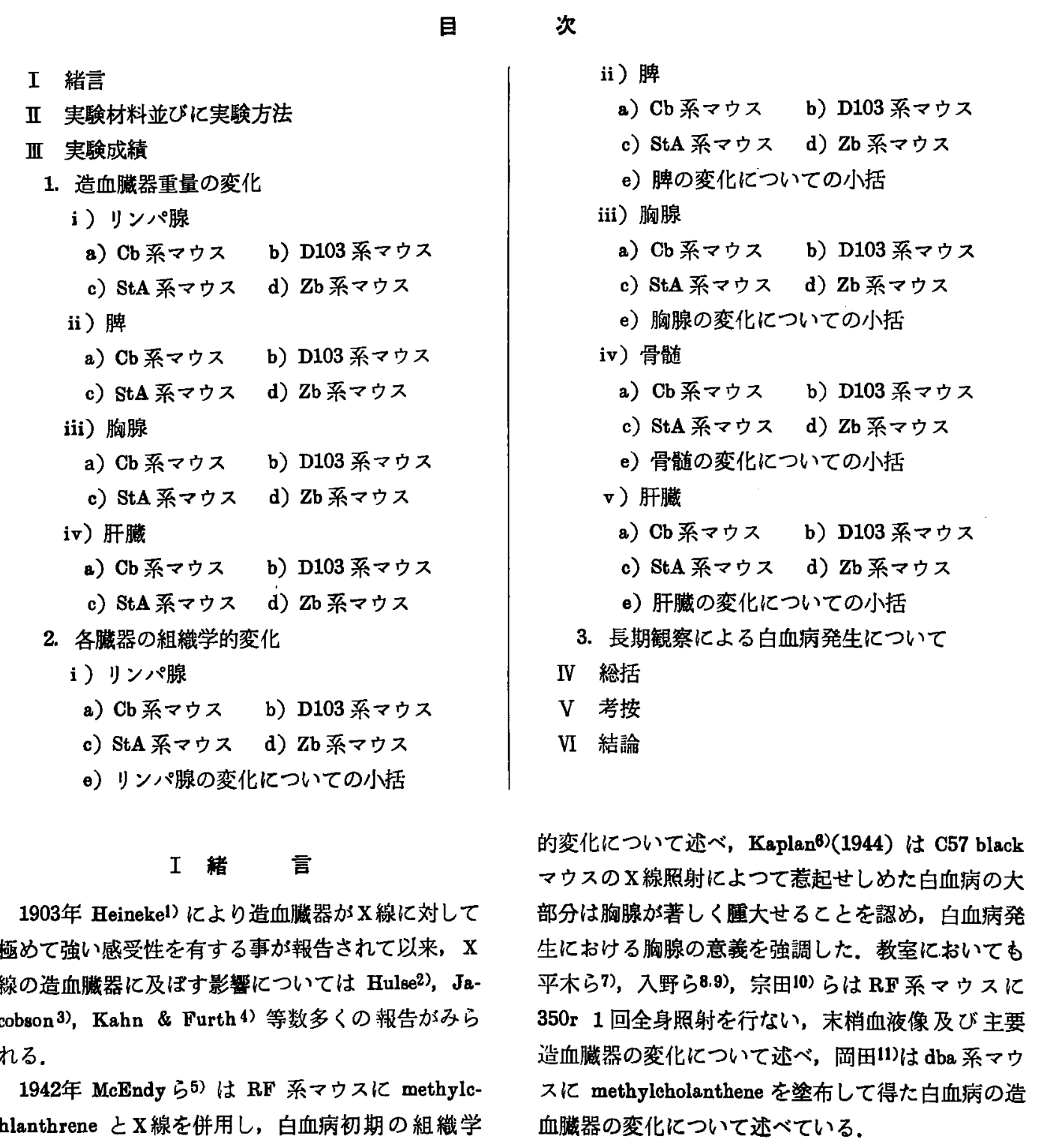


私はさきにX線により殆んど白血病の惹起されな い $\mathrm{Cb}, \mathrm{D} 103, \mathrm{StA}, \mathrm{Zb}$ 系マウスにX線を照射し， 末梢血液像の変化を追求し， $\mathrm{X}$ 楾照射により白血病 が高率に新発される RF 系マウスのそれとを比較し て 2,3 の興味ある知見を得たが，今回は上記 4 系 統マウス主要造血臟器の $\mathrm{X}$ 線照射後の変化を RF 系 マウスのそれと対比せしふつつ追求した。

\section{II 実倹材料並ひに実硂方法}

实験動物：1958年 Baylor University (Houston, U.S. A. ) より分变され，爾来本学マウスコロニー にて兄佅交配により慗殖飼育せる $\mathrm{Cb}, \mathrm{D} 103, \mathrm{StA}$, $\mathrm{Zb}$ 系マウスを使用した。 上記 4 系統マウス共白血 病の自然発生は殆んどみられない所謂白血病嫌発系 マウスである．マゥスは四季を通じ $20 \sim 24^{\circ} \mathrm{C}$ の恒 温純系マウス室にて飼育し，飼料はオリエンタル製 実験用固型飼料及び水を自由に食せしめた．X線照 射時期は生後30〜50日を選び，䧳婔はほぼ同数とし た。

$\mathrm{X}$ 線照射条件：前回の実験と同様 $200 \mathrm{kvp}, 15 \mathrm{~mA}$, $3 \mathrm{mmAl}$ 滤過板を使用, 照射距雜 $84 \mathrm{~cm}, 33.5 \mathrm{r} /$ 分, 照射時間 10.45 分亡し総量 350r 1 回全身照射した.

採血及び檪本作製： $\mathrm{X}$ 總照射後 2 日目， $1,2 ， 3$ ， $5,7,9,11,13,16$ 週目に対照としてX線非照射 マウス 1 匹， $\mathrm{X}$ 線照射マウス 3 匹を選び尾静脈より 採血し検血した後にエーテル麻酔にて殺し，リンパ 腺（表在性頸部リンパ腺, 腋窩リンパ腺, 上腕リン パ腺及び鴫距リンパ腺を一括し)，胸腺，脾，肝㼄 を摘出し計量した後に大腿骨と共に10名ホルマリン で固定しへマトキシリンーエオジン染色を行ない鏡 検した. Melangeur, Bürker-Türk 氏計算盤は日本 血液学会検定のものを使用し，網状赤血球算 定は Pappenheim 氏法, 末梢血染色は MayGiemsa 氏染色を行なつた。

坟期観察 : Cb 系マウス 우, 合17計20匹, D103 系マウス 우8，な10尌18匹，StA 系マウ ス우11, 令 8, 計 19 匹, $\mathrm{Zb}$ 系マウス 우 3 , 。 10 部 13匹に全く同一条件で 350r 1 回全身照 射を行ない，1ケ年間の長期観察を行ない白 血病発生の有然を観察した。

\section{III 実 匰 成 綪}

1. 造血㖪器重量の変化

i ) リンパ腺 (図 1 )

a) $\mathrm{Cb}$ 系マウス $\mathrm{X}$ 線整射直後約 $1 / 3$ に減
量し，以後次第に回復し，7週頃でほぼ正常大とな り 9 週目頃には鼠蹊リンパ腺の肥大したものが認め られた。

b) D103 系マゥス X楾照射後約1/5にまで減量 したが 1 週目で対照と同じくらいにまで回復し，以 後対照とほぼ同一の曲線を描いて増減した，X線照 射マウス, 非照射マウス共に重量の変化が激しかつ た.

c) StA 系マウス X 線照射後約 $1 / 2$ に減量しそ の後は漸次回復，増量したがあまり特徽的な变化は 認められなかつた。

d) $\mathrm{Zb}$ 系マウス 照射後の減量の程度は 4 系統 中最も轻度で回復も早く, 以後の変化も対照マウス とあまり差がなかつた。

ii) 脾 (図 2)

a) Cb 系マウス X線照射後 2 日目には約1/3に まで減量したが照射後 2 週目に到り急激に增量して 対照より重くなり 3 週目に再び減量した後次第に増 量した。

d) D103 系マウス $\mathrm{X}$ 線照射後の咸量は $\mathrm{Cb}$ 系マ ウスと同様であるが 2 週目の一過性增量は極めて者 明で 4 系統中最む著しかつた，以後は正常マウスの ものと同様であつたが，マウスにより個体差が大き 加つた。

c) StA 系マウス X 線照射後 2 日目， 1 週目の 减量は他系統と同様で, 又 2 週目の急激な増量も認 められたが程度は柽く，ほぼ対照と同じ大きさに止 まった. 以後は 3,5 週目に一時娍量した後は全く 対照と同一の変化を示した。

d) $\mathrm{Zb}$ 系マウス $\mathrm{X}$ 線照射後 2 日目， 1 週目の 娍量， 2 週目の増量は認められたがいずれも Cb，D
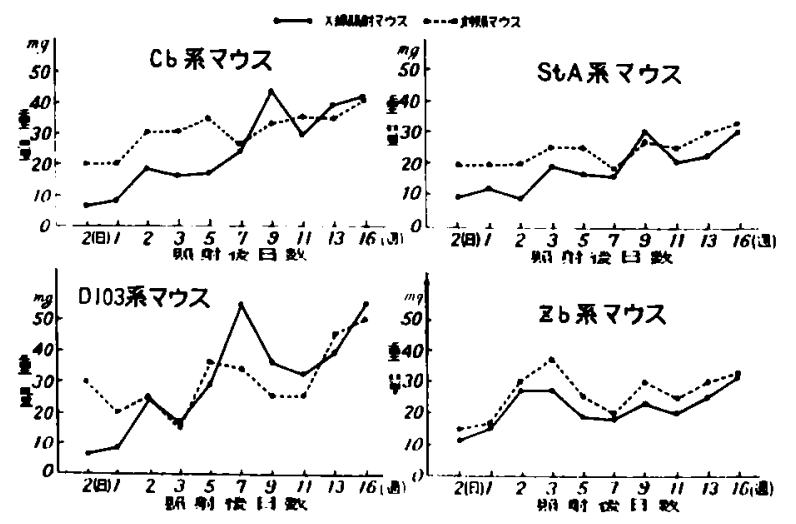

似 1 各種系統マウスにおけるX線照射侥のリ ンパ腚重量の変化 


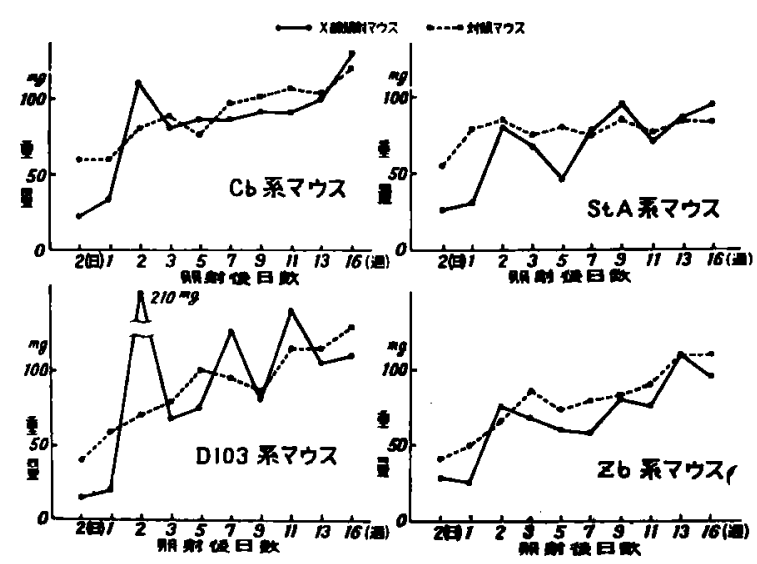

図 2 各種系絏マウスにおけるX線照射後の 脾重量の変化
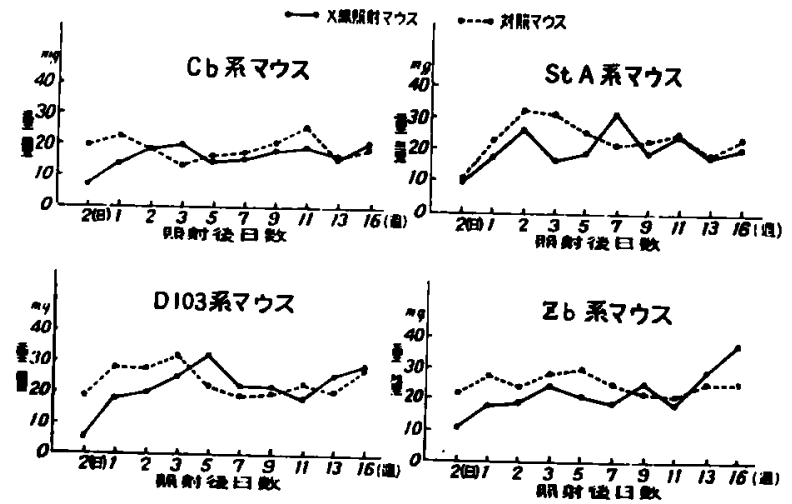

図 3 各種系統マウスにおけるX線照射後の 胸腺重宣の変化
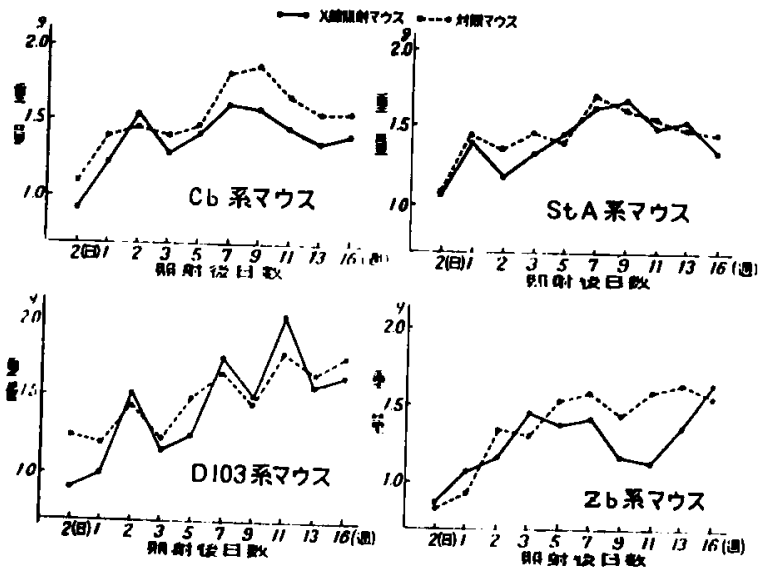

図 4 各種系統マウスにおけるX線照射後の 肝重量の変化
103 系マウスの如き著明なあのではなかつ た. 以後は他系統マウスと同様，一時減量 の後正常化した。

iii）胸腺（図 3 ）

a) Cb 系マウス X 楾照射後 2 日目, 1 週目は著明な减量が認められ，正常大に 州つた後11週目頃に対照よりやや肥大した あのをみた。

b) D103 系マウス 炤射後にはやはり 著明な娍量を認め， $5 \sim 7$ 週は対照よりや や重かつたか，対照マウス之共に変化が大 きかつた，又，Cb系とは逆に11週目に再び 減量が認められた。

c） StA 系マウス X 線炤射後の減量は ほとんど認められなかつたが 5 週まではい ずれも対照より小さかつた．7 週目以後は 対照之差は認められなかつた。

d） $\mathrm{Zb}$ 系マウス $\mathrm{X}$ 線照射後は著明に 減量し，炤射後 3 週目くらいでほほ正常と なり，13，16週目頃は対照より大きく，や や変形して塊状を呈するすのがあつた。

iv) 肝驖 (図 4)

a) Cb系マウス X線照射後 2 日目， 1 週目に娍量し 2 週目に一応回復したが以後 は常に対照より軽かつた。

b) D103系マウス 炤射後 2 日目, 1 週 目はかなりの程度に減量し，2 週目で回復 したが以後は照射群，対照群共変化が激し かつた。

c) StA 系マウス $\mathrm{X}$ 線照射による減量 は認められなかつた。

d) $\mathbf{Z b}$ 系マウス 照射直後の減量は認 められなかつたが 9，11過目に減量を諗め た.

2. 各戥器の組稚学的变化（図版 I, II)

i ) リンパ腺

a) Cb系マウス X 綄炤射直後, 表仕性 リンパ腺（表任性頸部リンパ腺, 腋窝リン パ腺，上腕リンパ腺及び鼠蹊リンパ腺)は 肉眼的にも縮小し，計量によつても約 1/3 程度に減量しているか，組織学的変化とし てはリンパ球の減少と拡散, リンパ湍胞の 萎縮, 変性, 壊死, Reticulm の萎縮, Sinus の拡張が認められた. $3 \sim 5$ 週目にか けては上記所見に網内系細胞の増生像加扣 
わる. 以後は次筍化回復に向いリンパ球の增生が盛 んに行なわれる様になり，一過性にプラスマ細胞を 認めたものもあつたが，リンパ球增生はいずれも成 熟細胞で幼若異型リンパ球の增生は認められなかつ た.

b) D103系マウス X 線照射後は Cb 系之同様に 変性, 壊死が認められ, 次で Reticulm の増生,リ ンパ球の増生が進行し，一過性に 9 週目頃単球及び プラスマ細胞の增生を諗めたものがある.

c) StA 系マウス X楾照射後の重量減少が $\mathrm{Cb}$, D103 柔ほど高度に認められなかつたのと同粎に組 織学的変化す柽度で变性, 罗死, 萎縮等はあまり認 められなかつた，以後は軽度にリンパ球增生，Fibrosis 等が行なわれたがプラスマ細胞の極めて盛ん な増生を認めたものがあつた。

d) $\mathrm{Zb}$ 系マウス 照射後 2 週目までは極めて怪 度の変性, 浮隀㑯向をみるのみで重量の減少が少な かつた事がうなづかれる．以後はリンパ球の増生が 極めて怪度にみられたのみて 4 系統を通じX線照射 の影踖が最む少なかつた。

e）リンパ腺の変化についての小括 $\mathrm{Cb}, \mathrm{D} 103$, $\mathrm{StA}, \mathrm{Zb}$ 系マウスに 350r 1 回全身照射を行なつた 後リンパ腺の変化を迫求したが, 重量の減少は $\mathrm{Cb}$, D103系マウスで大きく， StA系マウスでは約 $1 / 2 \mathrm{Zb}$ 系 マウスではさらに少なかつた， X線照射直後のリン パ腺減量はリンパ組織の变性, 壊死, 萎維によるが, 組織学的変化と重量の変化は全く平行した関係にあ つた. 又，末梢血液のリンパ球減少と組織学的变化, 重量の変化す互いに平行した関係にあるが， $\mathrm{Zb}$ 系 マウスの如く組織学的変化す重量変化む乏しい系統 においても末梢血中のリンパ球減少はかなり著明で あつた。リンパ組織が一たん受けたX線照射による 破壊加ら回復する過程において絀内系細胞の增生， リンパ球増生（大リンパ球増生）が認められた．又 一過性プラスマ細胞の增尘があつたが，いずれむ単 なる修復機転とみなされる変化で，㭃若細胞（白血 病細胞) の增生は認められなかつた。

ii) 脾

a) Cb 系マウス X $\mathrm{X}$ 線照射後 2 週目くらいまで 整血, リンバ細胞の変性，萎緶がみれ，滤胞，肧 中心の腫大, Sinus のカタル性炎病がみられ，以後 濾胞はやや萎綰し網内系細胞の增少:汃進行し滤胞周 包より漸次回復が行なわれる。X線による破罗像及 び網内系細犹の增に!は16週目に到るまで䛑められた。

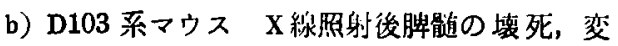

性，血筸膨化，一部に出血を認めたがすぐに修復機 枟がおこり，fibrosis， Riesenzellen の增生，リンパ 球增生が行なわれ，かなり著明な增生が行なわれた あのがあるがいずれる成熟リンパ球で白血病細胞の 浸潤を認めなかつた，又一部に単球增生を認めたも のがあつた。

c） StA 系マウス X線炤射後整血，出血，变性 等がみられ, 網内系緗胞の増生, リンハ球增生がこ れに次で進行するが，網内系細胞の増生が著明なの に対してリンパ球增生は他系統マウスに比し軽度で あつた.

d) Zb 系マウス X線照射直後の整血，出血， 変性等の変化は他系統マウスの如く著明でなく，リ ンパ㴓胞の腫大, 次で網内系細胞の増生リンパ球の 增生が行なわ机るがてれす StA 系マウスと同様汇軙 度であつた。

e）脾の変化についての小括 入野ら9)によれば RF 系マウスに 350r 1 回全身照射を行なつた場合， 脾は照射後 3 週目頃に一時的増量を示すか，今回の 実験で $\mathrm{Cb} ， \mathrm{D} 103 ， \mathrm{StA}, \mathrm{Zb}$ 系マウス共にいずれも $\mathrm{X}$ 線照射後 2 日目， 1 週目において減量が著明であ つたが 2 週目に到つて急漖に堌量してStA，Zb両系 統においてはほぼ対照之同程度, Cb, D103 系にお いては明かに対照より増量を示した，特にD103 系 マウスにおいて著明で，乙れは末梢血液において赤 血球数，血色装量が減少し網状赤血球が激增する時 期に一致し，その程度の最当激しかつた D103 系、 ウスにおいて重量の一時的増加が最も著しかつた事 はX線照射後の賓血か脾機能によつてかなり強い作 用を受けている事を示すものであろう．組蟣学的に みてX線照射直後においてリンパ細胞の変性，血， 盖胞胚中心の腫大, Sinus のカタル性炎症がみられ， 次で網内系細胞の增生が進行するが， $\mathrm{X}$ 線照射後 2 週目頃がその移行期にあたつている．脾滤胞の腫大 その他の変化が高度に達し重量が增加した後におい て诸胞はかえつて萎縮し，網内系細胞增生も未だ先 分でないため一時的に減量し，テの後渐次回復が行 なわれる.これらの変化は D103 系マウスにおいて

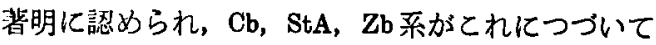
いた.

iii）胸腺

a) Cb系マウス X線照射後軽度の罗死, 変性加 衿められ， 3 週目頃から網内系緗胞の增生がはじま りリンパ球の增生が進行し，対照マウス肳腺よりも ややリンパ球增多が認められた。 
b) D103系マウス X線照射後には変性, 壊死 がかなり著明に認められ，照射後 3 週目頃からリン 八球增生が進行し，以後リン八゚球ははほ正常か又は 著明な増生を認めた。

c) StA 系マウス X線照射後軽度の変性, リン 八球減少がみられ，次で軽度に網内系細胞の増生及 びリンパ球の増生がおこつたが $\mathrm{Cb} ， \mathrm{D} 103$ 両系マウ スの如き著明なリンパ球增生は認められず，ほほ正 常化したのみに止まつた。

d）Zb系マウス X線照射直後は変性，リンパ球 の減少か認めら机たがすぐに回復に向い,リンパ球 は次第に増加してほほ正常化した後にリンパ被胞が 著明に肥大しリンパ球增生の盛んに行なわれている あのを認めた。

e）胸腺の変化についての小括 胸腺はマウス白 血病の発生に極好重要な役割りをしていると考え られている. 即ち従来マウスのリンパ性白血病は AKR マウスの自然発生白血病でも C57black, $\mathrm{C}_{3} \mathrm{~B}$ マウス等の X線照射による白血岍ですいずれる胸腺 に原発するといわれ19)13)，X線誘発 RF 系マウス白 血病化扰いても胸腺湟発するものがかなり多く， その他にも白血病発生における胸腺の重要な作用を 示す数々の実験6)12)14) がある. 一方又, 胸腺腫大の みられない C58 black 系マウスの自然発生白血病 や, 20-methylcholanthrene 誘発 dba 系マウス白血 病でも胸腺摘出によつて白血病発生率の低下するこ とから胸腺の関与が示唆されている.

$\mathrm{Cb}, \mathrm{D} 103, \mathrm{StA}, \mathrm{Zb}$ 系マウスに 350r 1 回全身照 射を行なつた場合, 多少の差はあつてすいずれの系 統においても胸腺は減量を示し，数週を経てはほ正 常に帰つた後はやや増量を示するのや，増量して变 形し塊状を呈したものを認めた．X線照射直後の胸 腺の減量は組蟣学的には変性, 壊死及びリンパ球の 減少のためであり，次で網内系細胞の増生之滤胞の 肥大, リンパ球増生が進行するため胸腺肥大, 変形 が起る. しかるに增生せるリン八球はいずれも成熟 細胞であり白血病細胞産生は認められなかつた。 か かる知見は Kaplan6) が C57 black マウスにX線を 照射した場合まず胸腺に急性退縮性障碍を来し，そ の修復機転の障碍によつて異常な過形成へと転じて 急性リンパ性白血病が発生すると述べ, 宗田 10)は RF 系マウスにおいて 350r 1 回全身照射後の造血 臟器の変化の詳勫な検索を行ない，胸腺においては 煦射 2 日後に障碍作用強〈, 続いて網内系細胞の增 殖, 更にリンパ球の反応㛗增殖に引き続いてかなり
早期より幼若リンパ球の增生がみられ，白血病が発 生すると報告したてとと考えあわせて興味深い。

iv）骨噵

a) $\mathrm{Cb}$ 系マウス X緑照射後軽度の変性が認め られ次いで骨髄細胞の増加が認められた。

b) D103系マウス $\mathrm{Cb}$ 系マウスと同様 $\mathrm{X}$ 線照射 直後に変性が, 次いで細胞増加が認められたが変化 は軽度であつた。

c) StA 系マウス 変化は軽度であつた。

d) Zb マウス 変化は軽度であつた.

c）骨髄の変化须ての小括 Cb, D103, StA, $\mathrm{Zb}$ 系マウスにおいて 350r 1 回全身照射後の大腿 骨骨䯣においては怪度の変性をみるのみで变化に之 しく，次いでおこる骨䯣細胞の増生す極めて軽度に 止まつた，しかるに一方リンパ腺, 脾, 胸腺等は $\mathrm{x}$ 線照射に対する感受性が大きく，破壊が強いため木 梢血において比較的好中球增多を示すものと劣えら れる. 又, 未梢血において赤血球数，血色珤量の著 明な減少之網状赤血球数の激増が認められるが, 同 じ時期の大腿骨骨髄像においては変性破壊像, 骨檤 細胞増生はいずれも怪度であつたが，一方骨䯣が極 めて大量な歲器であることを考えれば特に矛盾した 現象とは考えられない。

v) 肝眐

a) $\mathrm{Cb}$ 系マウス X 線照射後の変狌, 罗死が著 明で核の融解，細胞質に空胞化が認められた。再生 像は11週目頃より認められ, 又との頃から核の大き い肝細胞をみた。全時期においてX線照射による破 壊像が著明で16週に到るまで核及び細胞質に変性像 が明かであつた。

b) D103系マウス $\mathrm{Cb}$ 系マウスと同様に変性, 壊死が著明で 5 週目頃から小葉夙辺から再生が認め られた. しかし16週に到るむ変性像がかなり著明で あつた.

c) $\mathrm{StA}$ 系マウス 混濁腫張, 塤死, 変性か热め られ細胞の空胞化が目立つた.

d) Zb系マウス 他系統マウス之同様に壊死, 变 性，細胞の空胞化がX綜照射後 2 日目から16週目に 到るまで著明に認められた。

e) 肝荿の変化についての小括 Cb, D103, StA, $\mathrm{Zb}$ 系マウス共に重量の変化では多少の变動はあつ たが, 組織学的にはいずれも肝細胞の变性: 塄死が 著明で細胞質, 核共に空胞化が認められ，特に核に おいて著明であつた. 又X楾照射後 5 週目頃より小 集间辺から再生が行なわれたか，X線による破填像 
は16週に到るもなお著明に認められ，極めて大きい 核を有する肝細胞を認めた。

3. 長期観察による白血病発生について（表 $1 ， 2$, 図版 IIの 5-10)

表 1350 r 1 回全身照射に上る骨髄性白血 病マウス (C b 系) の末梢血液像

\begin{tabular}{|c|c|c|c|c|c|}
\hline 白 & 血 & & 球 & 数 & 38,900 \\
\hline & 骨 & 檤 & 芽 & 球 & $8(\not 6)$ \\
\hline & 前 & 骨 & 噵 & 球 & 3 \\
\hline 中 & 骨 & & 娟盗 & 球 & 6 \\
\hline \multirow[t]{2}{*}{ 球 } & 後 & 骨 & 檤 & 球 & 4 \\
\hline & 成 & 熟 & 好 中 & 球 & 72 \\
\hline ה & 小 & & & 計 & 93 \\
\hline 好 & & 酸 & & 球 & 1 \\
\hline 好 & 塩 & & 基 & 球 & 0 \\
\hline 単 & & & & 球 & 0 \\
\hline \multirow{4}{*}{$\begin{array}{l}\text { リ } \\
\text { ン } \\
\text { × } \\
\text { 球 } \\
\text { 系 }\end{array}$} & リ & ע & 八 芽 & 球 & 0 \\
\hline & 大 & リ & ン ハ & 球 & 2 \\
\hline & & & ע & 球 & 4 \\
\hline & 小 & & & 計 & 6 \\
\hline
\end{tabular}

表 $2350 \mathrm{r} 1$ 回全身照射飞よる骨琏性白血 病マウス (C b 系) の骨能像

\begin{tabular}{|c|c|c|c|c|}
\hline 赤 & 芽 & 球 & 系 & $18(96)$ \\
\hline \multirow{3}{*}{ 好 } & 骨 & 䁶 芽 & 球 & 21 \\
\hline & 前 & 骨 轓 & 球 & 13 \\
\hline & 骨 & 檤 & 球 & 14 \\
\hline+ & 後 & 骨＼cjkstart醀 & 球 & 16 \\
\hline 球 & 成 & 熟 好 中 & 球 & 18 \\
\hline \multirow[t]{2}{*}{ 系 } & 分 & 核＼cjkstart剖 & 像 & 0 \\
\hline & 小 & & 計 & 100 \\
\hline 好 & & 酸 & 球 & 0 \\
\hline 好 & 盐 & 基 & 球 & 0 \\
\hline 単 & & & 球 & 0 \\
\hline \multirow{5}{*}{$\begin{array}{l}\text { y } \\
\text { y } \\
\text { 球 } \\
\text { 系 }\end{array}$} & y & ン ハ 芽 & 球 & 0 \\
\hline & 大 & リ & 球 & 0 \\
\hline & 小 & リ ン ハ & 球 & 0 \\
\hline & 核 & 分＼cjkstart剖 & 像 & 0 \\
\hline & 小 & & ثا & 0 \\
\hline
\end{tabular}

前述の 4 系統マウスに同一照射条件で 350r 1 回 全身照射を行ない 1 年間の長期間にわたり白血病発 生を観察した.

D103 系マウス (ㅇ 8， 仓 10計18匹)，StA 系マウ

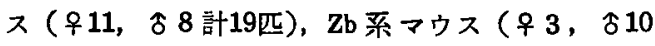
計13匹）においては 1 匹る白血病発生を認めなかつ たが，Cb系マウス（\&3，令17計 20匹）の令1匹 が X線照射後 4 ケ月で発症した．末梢血液像は表 1 の如くであつた，直ちに剖検したが胸腺は小指頭大 に原大し，胸腔の半ば以上を占め，組織学的にはか なり大きいリンパ球の無構造な增殖であつた，脾， 肝,リンパ腺の腫張は認められなかつたが脾は地図 状，樹枝状にリンパ增殖が認められ，肝細胞は再生 がすすみ細胞䡚はほぼ正常，核すかなりの程度に復 旧が認められた，留には变化を認めず，骨随には著 明な骨盈道細胞の增殖を認め，その骨骮像は表 2 の如 くで骨佮芽球21\%，前骨㵦球13\%，骨䯣球14\%，後 骨盛球16\%，成熟好中球 $18 \%$ で赤球系は18\%であつ た.

我々の教空においては白血病患者を始めとし諸種

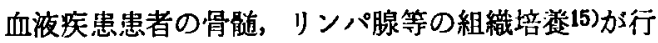
なわれ，各種知患により增生様式に特徴が認められ，

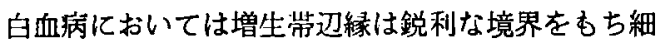
胞密度は極めて高い，乙㞦反再生不良性察血で は脂肪細胞多く增生帯辺縁は疎で細胞密度は極めて 低い，マウス白血病においては人の場合ほど定型的 ではないが自血病特有の増生を示すととが知られて いる。岡田(1)は前白血病期, 白血病初期に組織培 盗を行ない前白血病期には脾が, 白血病初期にはリ ンパ腺が白血病進展期には骨䯣が白血病性増生様式 を示す之述へ，平木ら16)は RF 系マウス白血病にお いて胸腺腫型は胸腺が，非胸腺腫型ではリンバ腺或 は脾が最初に急性リンパ性白血病の增生様式を示し たと述べている．前記 $\mathrm{Cb}$ 系マウスについて教室考 案の臨床組織培篮法15)を行なつたところ骨喵は細胞

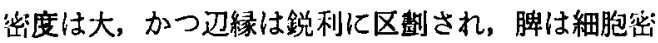
度は骨䯣にくらべて䟱で辺縁はやや鋭利であつた。

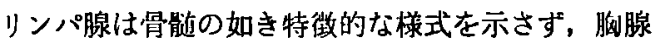
はほとんど增生带を認めなかつた。米梢血液像，組 㵶像, 組織培養の結果より骨髄性白血病と考えられ る. 又, 脾, 胸腺、リンパ腺による同系マウスへの 練挝移梢を試みたが成功しなかつた。

$$
\text { IV 総括 }
$$

1） 350r 1 回全身照射によりリンパ腺には変性, 
填死等の変化が起こり重量が減少した．この変化は Cb，D103 系マウスに著明でZb系マウスでは変化が 少なかつた．末梢血では各系統共にリン八球減少が 認められた。， $\mathrm{X}$ 楾による破填からの回復過程におい ては網内系細胞,リンパ球, プラスマ細胞の増生が 認められたが幼若細胞の増生は認められなかつた。

2）脾は細胞の変性，脾滤胞の肥大，等がま ず起とり次いで網内系細胞, リンパ球の增生が進行 した. 脾重量は X線照射後 2 週目頃に一時增加を認 め，末梢血において買血の著明な D103 系マウスに おいては脾腫が極めて大きかつた。

3）胸腺は X線炤射後変性，壊死，リンパ球減少 のため減量したが次第に回復した後腄張, 変形を示 した. しかし組織学的には網内系細胞の増生と滤胞 の肥大, 成熟リンパ球の增生のみに止つた。

4）骨䯣の変化は軽度に止まり，末梢血において は好中球よりリンパ球減少の方が強くおこるため比 較的好中球增多.を示した。

5）肝臓は各系統マウス共にX線照射により強い 影锌を受け, 変性, 壊死が強く, 核, 細胞質共に空 胞化がみられX線照射後16週目に到るもなお変性像 が著明であつた。

6) 1 年間の長期観察においては D103 系マウス 18匹，StA系マウス19匹，Zb系マウス13匹において は全く白血病の発生を認めなかつたが Cb 系マウス 20匹中 1 匹に骨髄性白血病が発生した. 脾、胸腺，

リンパ腺による同系マウスへの細胞移植は成功しな かつた.

\section{$\mathrm{V}$ 考按}

造血脸器が X線照射により極めて強い影響を受け る事は1903年 Heineke1)の報告に始まり, 爾来多 数の研究 2-4) があり，又， $\mathrm{X}$ 線炤射加発癌或は白血 病誘発作用をもち, 各種の白血病嫌発系マウスがX 線照射によつて白血病の惹起される事が知られてい る(7-25), 7-8).

$\mathrm{X}$ 線炤射による白血病の発生機序についても数々 の要团加関与している事が知られているが，造血臟 器及び末梢血液像の経時的変化についての研究は少 い. 宗田10) は RF 系マウスを用いてX線全身照射 によつて高率に白血病を起させ， $\mathrm{x}$ 線照射より白血 病発生に到るまでの末梢血液像及び造血藏器の変化 について経時的観察を行ない，末梢血液像において は白血球系に最す著明な特徽的所見がみられ，照射 2 日後激減，1 週目より回復に向い，1 月月後一度
正常值に復した後, 前白血病期に再び所謂 Hypoplastic となり，4 个月後より白血病が発生し末梢血 中にリンパ芽球の出現をみるに到ると述べている. 造血臟器の組織学的検索ではX線照射により障碍を うけた各臟器はかなり早期より反応性堌殖を示すが， 一部の例では胸腺から, 他の例ではリンパ腺或は脾 から白血病性変化が初発し, 白血病への進展をたど る所見を確認している.

私は第 1 編においてX線照射により白血病の発生 を殆んどみない $\mathrm{Cb}, \mathrm{D} 103, \mathrm{StA}, \mathrm{Zb}$ 系マウスを用 いて, $\mathrm{x}$ 線 350r 1 回全身照射後の末梢血液像を経 時的に観察し， $\mathrm{X}$ 線により白血病の高率に誘発され るRF系マウスとの比較を行ない，2，3の知見を得 て報告したが，今回はCb，D103，StA，Zb系マウス のX線照射後の造血臟器の变化の経時的検索を行な い若干の興味ある知見を得たので RF 系マウスと対 比しつつ考察を加えてみたい。

まず胸腺については，マウス白血病の発生におい て造血臟器中胸腺の役割りを重視する報告が多い. AKR マウス自然発生白血病や, X 線誘発 C57 black マウス白血病ではいずれあ胸腺に原発する(2)13)もの が大部分であり胸腺摘出によつて白血病発生が抑制 される14)27)，胸腺の腫大を伴わない C58 マウス自 然発生白血病や, methylcholanthrene 誘発 dba 系 マウス白血病でも，胸腺挡出によつてかなり抑制さ れる事が知られている。 入野8)9)，宗田10)らによれ ば白血病性変化が胸腺に初発し，その著明な腫大を 伴う胸腺腫型リンパ性白血球と, 脾又はリンパ腺に 白血病性変化が初発し, 胸腺の腫大を伴わない非胸 腺腫型リンパ性白血病がある. 胸腺腫型リンパ性白 血病では，胸腺は炤射 2 日後リンパ滤胞の著明な萎 縮がみられるが，かなり早期より網内系細胞の反応 性堌殖が起り，1 週間後からリンパ芽球栏の大きな 細胞の増殖がみられ, 7 週頃まで增殖は益々著明と なり, 早いあのではこの頃から奻若細胞の新しい結 節を作つて組織学的には白血病と思われる像を呈す るにいたる.この頃は末梢血中には幼若細胞の出現

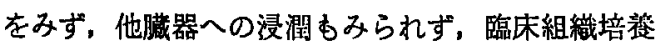
所見はむしろ低形成像を示すので, 恐らく胸腺の lymphosarcoma の状態であろう. 私の今回の実験に おいては, Cb，D103， StA， Zb 系マウスにおいて は 350r 1 回全身炤射後いずれも胸腺重量の減少, 組織学的には変性, 壊死, リンパ球の減少のため退 縮性の変化がおこり,引続いて網内系の反応性増殖 と成熟リンパ球増生を来し，ある例では稍幼若と考 
えられるリンパ球の著明な增狱を来するのもあつた が，いずれも反応性増殖の域を泔ず，白血病へ之進 展したものは1例も認められなかつた。ただ $\mathrm{Cb}$ 系 マウスの1例に骨剈过性白血病が発生し，てれに胸腺 肥大を伴つていたか，胸腺の臨床組織培養所見はす しろ低形成で，縕織学的にもリンパ球の反応性増殖 の域を出ず，胸腺に原発柴を有する白血病とは考え られなかつた，骨跹性白血病之胸腺㯵大との関係に ついては唯 1 则のみであるので何ともいえない.

次いでリンパ腺の変化は X 線炤射後のリンパ㥁胞 の萎縮, 变性, リンパ球拡散か認められ, 以後は網 内系細胞の増生, 一時的にプラスマ細胞増生, リン 八゚球增生をみ，かなり高度のX 線による破壊修復像 をみたが增生リンパ球はいずれも成就細胞であり， RF マウスの非胸腺腫型リンパ性白血病にみられた 照射後 7 週目頃のリンパ芽球の著明な増殖はみられ なかつた。

脾も全身リンバ組織の一つであり， $\mathrm{X}$ 線照射によ る変化もリンパ腺の変化と類似していたが，ただ脾 霹においてはX線照射後 2 週目において一過性に脾 厘を認めた例が多かつた. 岡田11)によれば 20-methylcholanthrene の投与をうけたdba 系マウスでは 白血病の病期進行と共に次第に高度の脾腫をみ, リ ンパ芽球の浸潤性增殖がおこり,リンパ腺は脾腫よ りやや遅れて腫張し，同様にリンパ芽球の增生が進 行して異型性が著明になると述べ, Dameshek 28) は 脾に原発したリンパ肉厙がリンパ性白血病に移行す る前に末梢血に抢いて㲸血球減少症即与脾機能六進 状態を示したと述へ，入野，宗田ら9》 RF 系マウ スにおいて照射後 3 週目頃に脾の一時的の増量を来 すととを認めている，RF系マウスにおいても，他 の純系マウスにおいてあX線照射後 1 ～ 3 週におい ては赤血球数, 血色䕀量, 白血球数の減少及び脾腫 を認めたが，RF 系マウスでは白血病への進展がみ られるのに反し，他の系統のマウスでは反応性之考 えられる一過性リンパ球増生のみに止り白血病への 進展はみられなかつた。

骨野の変化化関しては人の白血病において前白血 病期における低形成或は過形成を認めた之の報告は Dustin29), Marchal30), Mallarmé31), Block 32), Hayhoe33)，素多島 ${ }^{34)}$ 等によつてなさ机ており，渡辺 ${ }^{17)}$ はP32 によるマウス白血病において骨䯙の低形成状 態が白血病発生前にみられると述べた。. 今回の実験 においてX線照射後の骨䯣の変化は軽度の変性をみ るのみで,他の造血臓哭に比して柽く，末梢血液像に
おいては分血，白血球数の筬少をみたが，てれらの 変化は骨髄のX線による破塤によるのみならず, 同 時期におりる脾機能の一過性六進も加味しているも のと考えられる，又， $\mathrm{x}$ 線照射の影響は骨骮よりリ ンパ性增血作用の力に著明で，必然的に末梢血にお いては比較的好中球增多症を呈した。なお 1 例の骨 置性白血病の発生を $\mathrm{Cb}$ 系マウスにおいて認め, 乙 の白血病マウスでは腳腺の腫張は認めたが，胸腺の 臨床組織培養によつてはほとんど増生を示さず,一 方骨髄は定型的骨髄性白血病增生樣式を示した。 以 上の如く，1例の例外をのぞきCb, D103， StA, Zb 系マウスのすべては白血病発生をみず，組織学的に も $\mathrm{X}$ 線照射直後の変化は $\mathrm{RF}$ 系マウスとその他の系 統マウスとの間にかなりの相似点を認めたか，その 後の変化においては RF マウスと他系統マウスとは はつきりと異つた経過を示したが，乙れを表示すれ ば表 3 の如くである.

近年白血病ウイルス病原説が広く認められ，自然 発生マウス白血病のみならず, 白血病嫌発系マウス においてもX線照射により惹起せしめた誘発白血病 においてゥイルスの関与する事が認められてお り 36-41)，乙れらの知見から，RF 系マウスの如き白 血病溇発系でしかも線により白血病の誘発される マウスではウイルスを provirus の北ですでに有し ていることが想定され， $\mathrm{x}$ 線はこれを活性化せしめ るととによつて白血病を惹起させるのであろうとい われている. 或は又，マウスが本来ある種の抵抗因 子を有しており，x線がこの抵抗因子を破壊する事 によつて白血病を惹起させるか，或は又 $\mathrm{X}$ 線照射が ウイルスに対する缩主細胞の感受性を高めるために 白血病発生が容易になるとも考えられるが，加る 実験的証明は何らなされていない，てれに対して X 線照射により殆んど白血病の誘発さ机ない Cb, D103， StA，Zb 系マウス等はこの provirus を持たないか， 又は抵抗因子が䃨力でX線により活性化をみないと 考えられる.ウイルスの活性化が起こらぬ以上，末 梢血液像及び造血蔵器の組䋨像は 350r 1 回全身照 射後の短日内の变化に RF 系マウスと共通点をるる のみで，以後は全く異る变化をたどつて一方はリン ハ性白血病を発生し，他方は反応性増殖のみに止ま る事は当然であろう。しかし極めて低率てはあるが $\mathrm{Cb}$ 系マウスに白血病発生を認めた事は，これら 線非感受性マウスにあ 350r 1 回全身射のみでなく 他何らかの要因が加わればさらに解率に白血病発 生をみるのではないかとの期待を抱かせるものとい 
表 3 RF 系マウスとそれ以外の各種系統マウスの主要造血臟器に及ほす $\mathrm{x}$ 楾照射の影幚

\begin{tabular}{|c|c|c|}
\hline $\begin{array}{l}\text { 時 } \\
\text { 間 }\end{array}$ & Cb, D103, StA, Zb 系マウス & RF 系 $\mathbf{2}$ \\
\hline 初 期 変 化 & $\begin{array}{l}\text { 1. 骨檤, 脾, リンパ腺, 胸腺の変性, } \\
\text { 壊死 } \\
\text { 2. 重量の減少 } \\
\text { 3. } 2 \text { 週目頃に脾の一過性属張 } \\
\text { これらの変化は約 } 1 \text { ケで正常化 }\end{array}$ & 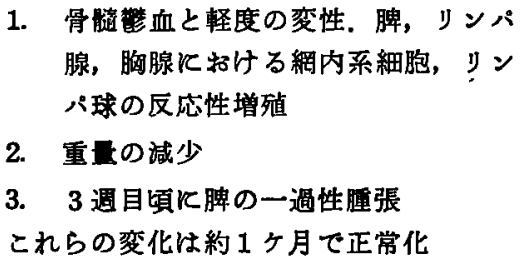 \\
\hline $1 ヶ$ 月 後 & $\begin{array}{l}\text { 網内系細胞, リンバ球, 骨䯕系細胞の増 } \\
\text { 生. 単球, フラスマ細胞の増加 }\end{array}$ & リンパ芽球の増殖，浸潤かなり著明 \\
\hline $3 \sim 4$ ケ月後 & $\begin{array}{l}\text { 脾, 䐢腺, リンパ腺の軽度肥大, 胸腺の } \\
\text { 変形 } \\
\text { 組織学的には成熟リンパ細胞の增生 }\end{array}$ & $\begin{array}{l}\text { リンパ芽球の増殖著明 } \\
\text { 組織学的には白血病の像 }\end{array}$ \\
\hline
\end{tabular}

※ 宗田10) とょる

えよう。

\section{VI 轺 論}

1）生後30〜50日の Cb, D103, StA, Zb 系マウ スに 350r 1 回全身照射を行ない末梢血液乙共に造 血臟器の变化を追求し, 又 1 ケ年間の長期観察にお いては D103 系マウス18匹，StA 系マウス19匹，Zb 系マウス13匹においては白血病発生を全く認めず， $\mathrm{Cb}$ 系マウスは20匹中1匹をのぞいて白血病発生を 認めなかつた。

2）Cb 系マウスに1例の白血病を認めたが，末 梢血液像及び組䅧培養から骨䯣性白血病である事を 確めた，胸腺腫張をみたが組織培塗ではほとんど増 生を認めなかつた，又，同系マウスへの細胞移植は 成功しなかつた。

3）リンパ腺，脾，胸腺は 350r 1 回全身照射後 は変性, 壊死, リンパ球減少を認め重量の減少をみ た。

4）脾はX線照射後 2 週目頃に一過性腫張をみ, 一過性脾機能元進症の状態を示した.

5）リンパ腺，脾，胸腺は重量減少後網内系細胞 及びリンパ球増生が進行したがいずれも成就細胞の 増殖のみに止まり異型細胞増生は認めなかつたが胸 腺の変形せるものを誌めた。

6）骨檤の変化は軽度に止まり，末梢血において
比较的好中球増多を示した。

7）以上に述べた造血臟器の变化は各系統におい て多少の変化はあるが，いずれすよく似た変化を示 し，特にその初期変化は RF 系マウスと全く同様で あるが， RF 系が比較的早期より幼若細胞の増生を 来すのに対し，反応性の成熟細胞増生のみに止まつ た. かかる所見をX線照射による白血病発生機構の 観点から考察した。

8）肝細胞はX楾による影副を強く受け，変性， 壊死, 空胞化は照射後16週に到るもなお著明であつ たが RF 系マウスにみられた様な特徽的な白血病細 胞浸潤は全く認められなかつた。

9）以上の所見から RF 系マウスは白血病誘発力 をもつ因子を provirus の形で持つており，X 線照 射によつて活性化されるのに対し Cb, D103，StA, Zb 系マウスは provirus を持たないか, 或はX楾照 射によつて活性化されにくい状態にあるのではない かと推論した。

㨄筆するにあたりご指導とご校閲を晹わつた恩阶 平木教授と入野講師及び組織標本についてご教示い ただいた本学病理木本講師に深謝いたします。

なお本論文の要旨は昭和37年10月，第 4 回日本放 射線影帮学会で発表した。 
1) Heineke, H.: Uber die Einwirkung der Röntgen-strahlen auf Tiere. Münch. Med. Wschr. 50, 2090-2092, 1903.

2) Hulse, E. V.: Quantitative studies on the depletion of the erythropoietic celles in the bone marrow of the Irradiated rat. Brit. J. Haemat. 3, 348-358, 1957.

3) Jacobson, L. O., Marks, E. K., and Lorenz, E. : The hematological effect of ionizing radiations. Radiology, 52, 371--394, 1949.

4) Kahn, J. B. and Furth, J.: The pathogenesis of postirradiation anemia. Blood, 7, 404-416, 1952.

5) McEndy, D. P., Boon, M. C. and Furth, J. : Indication of leukemia in mice by methylcholanthrene and $x$-rays. J. Nat. Cancer Inst., 3, 227-247, 1942.

6) Kaplan, H. S. and Kirschbaum, A.: Studies on synergism of leukemogenie agents in mice. Proc. Soc. Exper. Biol \& Med. 55. 262-264, 1944.

7) Hiraki, K., Irino, S. and Sota, S. : Studies on cytogenesis of RF mouse leukemia induced by x-ray irradiation. Puoc. 8th Congr. Europ. Soc. Haemat., 347, 1662.

8）入野昭三，小塚玩，宗田範： $\mathrm{X}$ 線照射により惹 起せしめたRF 系マゥス白血病に関する研究 第 1 報. 日本洫液学会雑誌，24，283-284， 1961.

9）宗田匴，入野昭三：X線照射により落起せしめ た RF 系マウス白血病に関する研究 第 2 報. 日本血液学会雑誌，24，284，1961.

10）宗田範：X線照射によるマウス白血病の発生機 構に関する研究 第 1 編 前白血病状態の変化 について. 岡山医学会雑誌 77, 1-23, 1965.

11) 岡田㓞一：20-methylcholanthrene Kよるハッ カネスミリンパ性腫埸の研究. 岡山医学会䧴誌, $72,1133-1195,1960$.

12) Kaplan, H.S.: On etiology and pathogenesis of leukemias: A review. Cancer Res. 14, 535 $-548,1954$.

13) Potter, J. S., Victor, J. and Ward, M. A. : Histological changes preceding spontaneous lymphatic leukemia in mice. Am. J. Path. 19, 239-253, 1943.

14) Law, L. W. \& Miller, J. H. : Influence of thymectomy on incidence of carcinogen-induced leukemia in strain DBA mice. J. Nat. Cancer Inst. 11, 425-437, 1950.

15) Hiraki, K. : Studies on diagnosis of leukemia by tissue culture. Acta Medicinae Okayama, 12, 84, 1958.

16）平木潔, 岩崎一郎, 有森茂, 川西泰男, 宗田箶 : 放射線照射に上り惹起される実験的白血病に 関する研究 特に ACTH 飞よる白血病吐生予 防について. 綜合臨牀，12，1219-1227， 1963.

17) Duplan, J. F.: Les Radioleucémies expérimentales: la semaine des hopitaux Pathologie-Biologie. 33, 1559-1578, 1957.

18) Furth, J. \& Furth, O. B.: Neoplastic diseases produced in mice by general irradiation with $X$-rays. I. Incidence and types of neoplasms. Am. J. Cancer. 28, 54-65, 1936.

19) Henschaw, P. S. : Experimental Roentgen Injuy. Picture, Tissue morphology and life span in mice. J. Nat. Uancer Inst., 4, 513-522, 1944.

20) Hueper, W. C.: Leukemia and leukemic conditions in white mice with spontaneous mammary carcinomas. Folia Haematol, 52, 167178, 1934.

21) von Jagic, N., Schwarz, G. and von Siebenrock, L.: Blutbefunde bei Roentgenologen. Berlin. Klin. Wchnschr., 48, 1220-1222, 1911.

22) Kaplan, H. S. : Observations on radiationinduced lymphoid tumors of mice. Cancer Res., 7, 141-147, 1947.

23) $K$ plan, H.S.: Influence of age on susceptibility of mice to the development of lymphoid tumors after irradiation. J. Nat. Cancer Inst., 9. 55-56, 1948.

24) Kaplan, FI. S.: The pathogenesis of experimental lymphoid tumors in mice. Proc. Soc. Canadian Cancer Conf. p. 127. New York, Academic Press, 1957.

25) Kaplan, H.S. and Brown, M. B. : mortality 
of mice after total body irradiation as influenced by alterations in total dose fractionation, and periodicity of treatment. J. Nat. Cancer Inst., 12, 765-775, 1952.

26) Krebs. C., Pask-Nielsen, H., and Wagner, A. : The origin of lympharcomatosis and its relation to other forms of leucosis in white mice. Acta Radiol., Stockholm (Suppl.), 10, 1-53, 1930.

27) McEndy, D. P, Boon, M. C. and Furth, J.: On the role of thymus, spleen and gonads in the development of leukemia in a high-leukemia stock of micc. Cancer Res. 4, 377-383, 1944.

28) Damerhek, W.\& Gunz, F.: Leukemia. Grune \& Stratton. New York a d London, 1958.

29) Dustin, P., JR.: Myélose aplasique récidivante chez un e fant. Crise leucémoide aiguë terminale. Sang, 16, 394-399, 1944-45.

30) Marchal, G., Deprez, V. and Blanc, G.: Syndrome agranulocytaire par chimiothérapie, transformé en cryptoleucémie aiguë à évolution lente. Sang, 16, 133-138, 1944.

31) mallarmé, J.: Les débuts hématologiques des leucoses malignes. Sang, 20, 420-433, 1949.

32) Block, M., Jacobson, L. O. and Bethard, W, F.: Preleukemic acute human leukemia. J. A. M. A. 152, 1018-1028, 1953.

33) Hayhoe, F. G. J. : The Leukemias. Etiology, Pathophysiology, and Treatment. Academic Press Inc., Pablishers New York. 1958.
34）喜多島康一，品川晃二，島崎孝一，林信㕕：前 白血病状热を把握しえた 2 症例，とくにその骨 盛培養所見の推移について：内科，8，1173$1180,1961$.

35) 渡辺渐：放射性同位元索（P ${ }^{32}, \mathrm{St}^{89}$ 及び Ce $\left.{ }^{144}\right)$ の内部照射による甘日鼠の実験的白血病につい

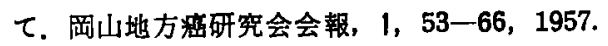

36) Grose, L.: Attempt to recover filtrable agent from X-ray-induced leukemia. Acta Haemat. 19. 353-361, 1958.

37) Gross, L.: Serial cell-free passage of a radiation-activated mouse leukemia agent. Proc. Soc. Exp. Biol. \& Med. 100, 102-105, 1959.

38) Lieberman, M. \& Kaplan, H. S. : Leukemogenic activity of filtrates from radiationinduced lymphoid tumors of mice. Science, 130, 387 -388, 1959.

39) Parsons, D. F., Upton, A. C., Bender, E. S. and Jacobson, R. R. : Electron microscopic observations on primary and serially passaged radiation-induced myeloid leukemias of RF mouse. Cancer Res., 22, 728-736, 1962.

40）平木滋，入野昭三，宗田範，池尼孝治：X線照 射により惹起せしめた RF 系マウス白血病の哭 和胞腹液移植飞関する研究. 日本血液学会雑誌， 25, 816-821, 1962.

41）入野昭三，太田善介，宗田範: $\mathrm{X}$ 線誘発 RF 系 ハツカネスミ白血病に㧍けっイルスの電子影 微鏡に上る証明とその䒜細胞㴼液移植実験。医 学と生物学, 67, 162-168, 1963.

四版 I 各種系統マウスに括けるX線照射後の各脿器の組織学的変化

1ー4: リンパ腺

$1 ： \mathrm{Cb}$ 系マウス 照射後 2 遇目. 重量減少, リンパ球減少し細胞密度は䟱. (100×.)

2 ：StA 系マゥス 照射後11週目。大リンバ球及びブラスマ細胞の增生著明. (100x)

3 : 同上. 強拡大 $(400 x)$

4: Zb 系マウス 照射後11週目. リンパ球の增生と単球, フラスマ細胞, 棢内系細胞の增生. $(400 \times)$

$5-8:$ 脾

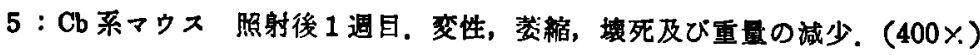

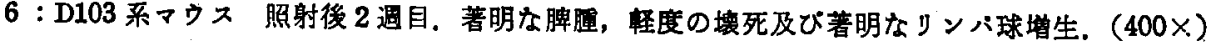

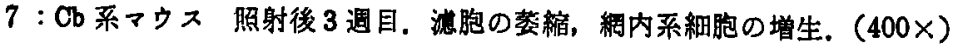


$8: \mathrm{Zb}$ 系マウス 照射後 7 週目。港胞の肥大, 脾静脈周囲にリンパ球增生著明で,や」無構造化.

$(100 \times)$

$9-10:$ 胸腺

9 : D103 マゥス 照射後 2 日目. 変性, 壊死, 重量減少. $(400 \times)$

10 :StA 系マウス 照射後 1 週目。一部に变性, リンパ球減少, 一部にリンパ球增加. (100×)

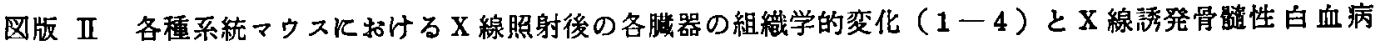

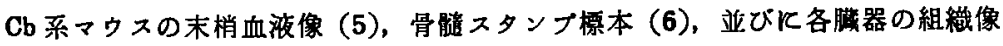

$1-3:$ 眴腺

$1: \mathrm{Cb}$ 系マゥス 照射後 5 週目，網内系細胞の著明な增生. $(400 \times)$

$2: \mathrm{Zb}$ 系マウス 照射後11週目, 重最の增加, 塊状を呈し犬リンパ球の增生著明.（100×）

3 : 同上. 強拡大 $(400 \times)$

4 : 所 $\mathrm{Cb}$ 系マゥス 照射後 2 週目。変性。壊死, 核及び細胞質の破壊と空胞化. (100x)

5-10：X線照射飞より惹起された骨链性白血病マゥス（Cb 系）

5 : 末梢血液像 $(1,000 \times)$

6 : 骨檤スタンプ標本 (May-Grünwald-Giemsa 染色). $(1,000 \times$ )

7 : 脾 地図状，樹枝状にリンパ球堌生. (100×)

8 : 胸腺 著明な肥大, 無構造な大リンパ球の著明な増生.（100×）

9 : 同上. 強抬大. $(400 \times)$

10：肝 再生すすみ肝細胞はほほ正常, 白血病細胞の軽度の浸潤。（400X）

\author{
Experimental Studies on X-ray and Leukemia \\ part 2. A Comparative study of the Effect of X-Irradiation on \\ Hematopoietic Organs in Various Strains of Mice
}

Koji Ikejiri

Department of Internal Medicine, Okayama University Medical School

(Director: Prof. Kiyoshi Hiraki)

In the series of studies being conducted on radiation leukemogenesis, observations lasting for one year were carried out to see the changes in the hematopoietic organs with lapse of time, using 30-50 days old mice of the $\mathrm{Cb}, \mathrm{D} 103, \mathrm{StA}$, and $\mathrm{Zb}$ strians after a single whole body X-irradiation of $350 \mathrm{r}$. The findings of the study are presented in the following.

1. In the observations lasting for one year, there was no development of leukemia in 18 mice of the D103 strain, in 19 mice of the StA strain, and in 13 mice of the Zb strain. In one out of 20 mice of the $\mathrm{Cb}$ strain, however, leukemia did develop, and it was confirmed to be myelogenous leukemia from its peripheral blood picture and tissue culture. Cell transplantations from this mouse to other mice of the same strain were not successful.

The changes in hematopoietic organs occurring with lapse of time after X-irradiation in aech strain of mice that did not develop leukemia are as described as follows.

2. Lymph nodes, spleen and thymus after the irradiation showed degeneration, necrosis and lymphoctyopenia, with a decrease in their weight.

3. Two weeks after the irradiation the spleen was transiently enlarged, showing an acceleration of splenic function. This was striking in mice of the D103 strain.

4. After the decrease in the weight of lymph nodes, spleen and thymus, the proliferation 
of reticuloendothelial cells and lymphocytes was accelerated, but this tendency in any organs was limited to the proliferatioan of mature cells only. There could also be recognized distortion of thymus in some.

5. The changes in the bone marrow were slight and the peripheral blcod showed a relative neutrophilia.

6. These changes were similar in each strain of mice, especially those changes in the initial stage were exactly identical with those observed in RF strain mice. In the RF strain mice, however, young cells proliferated at a relatively early stage whereas in the resistant strains such as the $\mathrm{Cb}, \mathrm{D} 103$, StA and $\mathrm{Zb}$ strains the reactive proliferation of only mature cells could be observed.

7. Liver cells were greatly affected by X-ray, showing degeneration, necrosis, and vacuolization even 16 weeks after the irradiation, but no specific infiltration of leukemic cells as in the case of mice of the RF strain could be demonstrated.

From these findings it is assumed that mice of the RF strain possess leukemogenic factor in the form of provirus and this is activated by $\mathrm{X}$-irradiation, while mice of the $\mathrm{Cb}, \mathrm{D} 103$, StA or Zb strains do not have provirus or has provirus in a state in which it is difficult to be activated by X-irradiation. 


\section{池尻論文四版 I}

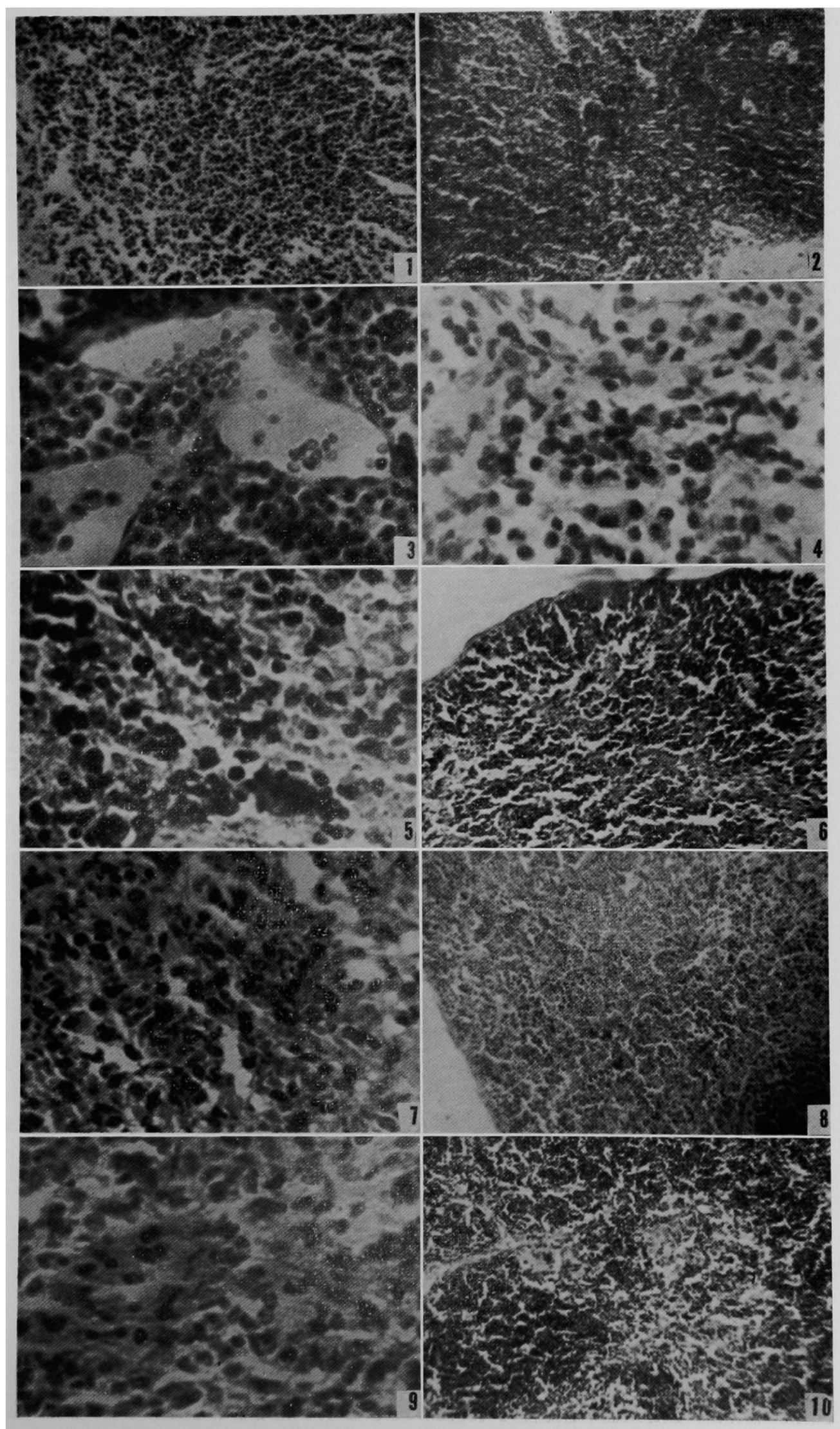



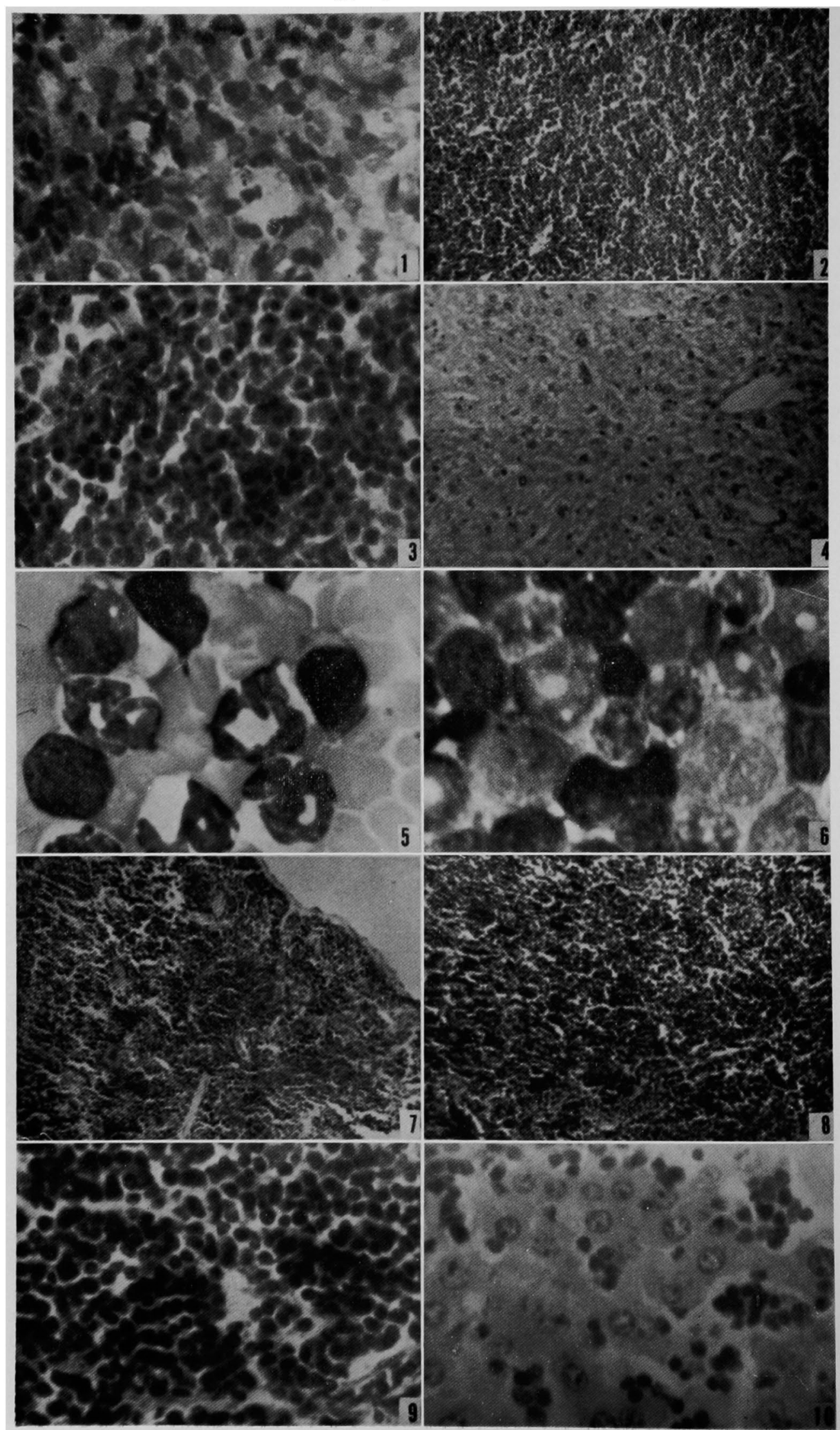